\title{
REGIONAL HONEYS IN POLAND IN 2010-2015
}

\author{
Agnieszka Borowska ${ }^{1}$ \\ ${ }^{1}$ Warsaw University of Life Sciences WULS - SGGW
}

\begin{abstract}
The situation of producers of five Polish regional honeys certified with the Protected Designation of Origin and the Protected Geographical Indication logos is shown. The specifics of production, distribution, prices and prospects for their presence on the Polish market is presented. Besides, attention is drawn to the structure of net prices (producers) and retail prices of such regional honeys, i.e. the Kurpie honey, the heather honey from Bory Dolnoslaskie forests, the Podkarpacki honeydew honey, the honey from Sejny county, and the Drahim honey. The study is a continuation of research initiated within the framework of research project $\mathrm{N}$ N112 057234 of the Ministry of Science and Higher Education and N N112 374540 of the National Science Centre. Regional honeys with PDO and PGI quality markings are a new phenomenon on the Polish market. For producers, they are a challenge in the production certification process according to the specification, thanks to which the PDO or PGI logo can be used on the honey packaging. Their sale mainly takes place within short distribution chains and demand exceeds supply. Consumers see a high-quality product in regional honey, and thus position it higher in relation to other honeys, which is why the interest is growing.
\end{abstract}

Key words: regional honeys, PDO, PGI, production, prices

JEL code: Q11

\section{Introduction}

With Poland's accession to the EU in 2004, both institutional and social actions were intensified with the aim to make Polish producers register their quality traditional and regional products as the Protected Designation of Origin (PDO), the Protected Geographical Indication (PGI) and the Traditional Speciality Guaranteed (TSG). Among all the 1341 food products registered by the European Commission, 680 are listed as PGI, 607 as PDO and 54 as TSG. By 2015 Poland registered 37 products (19 as PGI, 9 as PDO, and 9 as TSG), which gave our country the 6th position in the ranking before Italy (284), France (229), Spain (192), Portugal (134), Greece (103), Germany (86) and the UK (59) [European Commission, Agriculture and Rural Development 2016]. The most popular categories of foods subject to quality registration systems include: fruit, vegetables and fresh or processed cereals (369 products), cheeses (233), processed meat products (177), fresh meat (and offal) (151), oils and fats (butter, margarine, oils, etc.) (128), bread, cake, biscuits and other bakery products (72), and other products listed in Annex I to the Treaty (59). Another category comprises 45 so called other categories of products of animal origin (eggs, honey, various milk products except butter etc.). It includes 32 honeys (24 with PDO and 8 with PGI designations), of which 5 originate from each of the following Member States: Poland, France, Spain, 9 are from Portugal, 4 from Italy and 3 from Slovenia. A very popular category includes also fresh fish and sea fruit (45 products), beer (26), confectionery, bread and bakery products (13). The system protects also pastas, hey, fragrance oils, wool, carminic acid, flowers and plants. Having regard to a short 10 -year period of building the Polish market for certified quality foods, since the time of registration of the first Polish quality regional product, a Podhale bryndza cheese (PDO), and the first honey (PGI certified heather honey from Lower Silesia Forests), it is worthwhile to discuss the historical, institutional, social, economic or cultural aspects related with those original Polish products, especially in the context of the initial stage developing market of those products in Poland. Considerable fragmentation and apiaries often run by amateurs are characteristic for the beekeeping in Poland. Honey is the main source of income for the beekeepers other bee products are produced in small amounts. Most of honey is sold directly to the consumer. The average consumption of honey per person still remains at a stable though low level of 0.5 to 1 
$\mathrm{kg}$ per annum. The cheaper varieties and those harvested annually (eg. the multifloral and rape honeys) dominate in the structure of honey consumption in Poland, while the seasonally variable honey species (depending on flows) such as the heather and honeydew honey (eg. of coniferous honeydew ) are increasingly popular. Regardless of the form of sale, the heather and honeydew honey from coniferous honeydew are the most expensive in Poland while prices of the rape and multifloral honey are the lowest. The demand for the regional honeys has been steadily increasing over the years thanks to the long-term development of consumers' awareness by beekeepers who have educated the public about their products and built consumer confidence in the repeatedly guaranteed premium quality of their products. The direction of changes in consumer preferences allows a conclusion that niche products and direct sales of low-processed foods produced according to traditional recipes will create the chance for Polish producers to develop their businesses, especially small-scale activities.

\section{Research results and discussion}

The objective of this article is to present the situation of regional honey on the Polish market, with particular regard to honey with the recognized EU geographical certification - the protected designation of origin and the protected geographical indication. The primary and secondary sources of information were used in the study, first came from the research conducted in 2012 and 2014 and February-April 2016 by all 5 associations of the certified beekeepers producing: Kurpiowski honey, heather honey from Bory Dolnoślaskie forests, Podkarpackie honeydew honey, honey from the Sejny county, and Drahim honey, and the research carried out within the framework of N N112 374540 project financed by the National Science Centre. The statistical reports used in this study included the data of the Ministry of Agriculture and Rural Development, Rural Development Programme 2007-2013 and Agency for Restructuring and Modernization of Agriculture. In the analysis of the research problem the comparative and descriptive methods were used.

\section{Regional honeys}

The consumers in Poland and in the other country pay more and more attention to the quality of food sold on the market [Zakowska-Biemans 2011, Kühne B. et. 2010, Popovics 2006, Verbeke, Roosen 2009]. The consumer ethnocentrism is observed and the organizations of producers actively promote the healthy food. Besides, the initiatives taken within the framework of publiclegal-social partnerships (eg. Local Action Groups - LAGs) show the richness of the country's cultural heritage, including the culinary culture. Locally, especially in the rural areas, the social ties are revitalized not only by bringing the residents together (e.g. in such activities as rural housewives' circles, folk bands, beekeepers' circles), but also by enhancing alternative sources of income from available regional resources which includes the apiaries. The seasonal events cultivating traditions of the ancestors (e.g. the beekeeping demos) or showing, especially to the younger generations, the specifics of "ancient" occupations (such as cooper, blacksmith, saddler, beekeeper etc.), and also creating an opportunity to sell the locally produced regional specialties (including honey, wax candles, and the like) and handicrafts, that are popular not only among local residents demonstrate the long-term and multiple-direction support provided by the public institutions (central and local government agencies, chambers of agriculture, trade unions, agricultural advisory centres, cultural centres etc.). Taking into account the experience of European consumers gained from the shocking food safety scandals in the last decade only, also the Polish 
consumer is more and more conscious in making purchase decisions. Increasingly, not only the economic factors (such as price or income), but also the non-economic ones such as quality of products, health benefits, natural composition, and components used in processing, reinforce their top position in the purchase determinant lists [Vecchio, Annunziata 2011, Pieniak, Verbeke, et 2008]. No wonder that a conscious buyer pays attention to labels, markings and inscriptions marking organic food, traditional mode of production, no preservatives used, no artificial colors used, of regional origin, certification etc.) [Fragata, Tiberio, Teixeira 2007, Vecchio, Annunziata 2011, Borowska 2010a, 2010b]. Also the regional honeys belong to natural products sought-after by Poles. Great in number and diversity the regional honeys give the consumers plenty to choose from. The number of 1524 products $^{1}$ registered before 12 March, 2016 in the List of Traditional Products kept under the auspices of the Minister of Agriculture and Rural Development from 2005 give evidence of the above statement. The List of Traditional Products comprises 62 honeys, among them five regional honeys that were granted the PGI certificate (heather honey from the Bory Dolnoslaskie forests, Kurpie honey, Drahim honey) and the PDO certificate (Podkarpacie honeydew honey and honey from the Sejny county) at the European Commission level [Borowska 2011]. Besides, other popular honey species are available on the market: nectar (multifloral) honey, quality (rape, acacia, lime, buckwheat, heather) and, although on a smaller scale, rarer honey species (dandelion, raspberry, starflower, goldenrod, phacelia honeys), nectar - honeydew honey and (deciduous or coniferous) honeydew honey. Most of them are sold directly to individual buyers in an "at the door" system i.e. in the apiaries or during local cultural events (such as product days, fairs, festivals, special events) as well as in places the specially designed for trading (markets, fairs, bazaars) etc [Borowska 2009].

The short chains of supply are also preferred by the certified beekeepers producing five Polish regional honeys, including three with PGI and two with PDO logos. The end consumers of such honeys are mainly the local residents and loyal buyers who annually repeat purchases of the preferred varieties of honey among them. In addition to shopping by the individuals, more and more beekeepers note groups of buyers, i.e. tourists or organized groups ordering larger batches, also by telephone or, as in the case of Drahim honey where orders of for instance sets of honey varietals are made online www.pasiekafujarskich.pl. However, due to the current niche scale of regional honey production, the cooperation of sellers with retail units (such as healthy food stores, herbal stores, retail stores etc.) is sporadic. The sales of regional honey to stores or other entities (for instance public education units - schools, kindergartens, nurseries etc.) impose on a beekeeper an obligation to issue a VAT invoice, and therefore only a few beekeeping farms - mainly the commercial apiaries (in 2011-2014 there were 8-12 commercial apiaries among the certified beekeepers) decide to conduct such business activity (Table 1 ). The solution proposed by the Provincial Association of Beekeepers in Rzeszów, which cooperates with the interested certified beekeepers (1-3 until now) and distributes the Podkarpacki honeydew honey in the branded outlet, is an interesting initiative. Three beekeepers - members of the Association of Drahim Honey Producers worked out a competitive edge over other regional producers of regional honeys by developing modern channels of distribution through their online branded outlet. However, in particular from the point of view of prospective buyers of honeys with PDO and PGI logos who use modern tools of communication (telephone, Internet), there is a considerable hindrance, namely

${ }^{1}$ http://www.minrol.gov.pl/Jakosc-zywnosci/Produkty-regionalne-i-tradycyjne/Lista-produktow-tradycyjnych 
the lack of identified and well-indicated places or contract data with current telephone numbers and addresses of all certified producers. Also, the producers themselves confirm that situation by pointing out that computers are not used in the apiaries run by beekeepers of older generation (over 65 and often more than 80 years old), though they are sometimes supported in using IT by family members. Own websites are developed mainly by the beekeeping farms run by the younger generation. Therefore, still the best way to buy such products is either in an apiary, or at seasonal fairs, trade fairs, beekeeper days or folklore events (such as the Kurpie Honey Harvest held from 1977, Dolnoslaski Honey and Wine Festival, Podkarpacki Honey Feast).

Table 1.

\section{Number of producers with quality certificates authorizing the marketing of honey registered as PDO, PGI in 2008-2015}

\begin{tabular}{|c|c|c|c|c|c|c|c|c|c|}
\hline Honey: & Registration & $\stackrel{\infty}{\circ}$ & : & $\begin{array}{l}0 \\
\text {-1 } \\
\text { N }\end{array}$ & $\stackrel{-1}{\text { - }}$ & $\underset{N}{N}$ & $\stackrel{m}{\stackrel{m}{+}}$ & 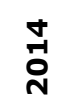 & $\stackrel{\text { n }}{\overbrace{\text { N }}}$ \\
\hline $\begin{array}{l}\text { Miod wrzosowy z Borow } \\
\text { Dolnoslaskich } \\
\text { Honey from Lower Silesia Forests }\end{array}$ & $31 / 05 / 2008$ & 2 & 2 & 2 & 4 & 6 & 5 & 5 & 1 \\
\hline Miod kurpiowski - Kurpie honey & $13 / 07 / 2010$ & & & 9 & 15 & 22 & 11 & 11 & 11 \\
\hline $\begin{array}{l}\text { Podkarpacki miod spadziowy } \\
\text { Sub-Carpathian honeydew honey }\end{array}$ & 07/08/2010 & & & & 7 & 0 & 14 & 14 & 1 \\
\hline Miod drahimski - Drahim honey & $16 / 06 / 2011$ & & & & 5 & 5 & 5 & 5 & 5 \\
\hline $\begin{array}{l}\text { Miod z Sejnenszczyzny - The honey } \\
\text { from Sejny }\end{array}$ & $30 / 01 / 2012$ & & & & & 2 & 2 & 2 & 2 \\
\hline
\end{tabular}

Source: GIJHARS 2016

It results from the previous studies of the author (in the years 2012-16) that the certified regional honeys (heather honey, Podkarpacki honeydew honey) are sold in the harvest season by the end of a calendar year at the latest. The demand for such honey exceeds the supply. Even in the favorable years of production (2008-2015) the previous year's stock did not remain in the apiaries. Moreover, due to unfavourable weather conditions and lack of honey flows in the examined period the shortages of the two honey species: heather honey from Bory Dolnoslaskie forests and Podkarpacki honeydew honey were noted. Despite the fact that in the regions where 5 regional honeys are produced only a few dozens of the several hundred beekeepers - producers of e.g. Kurpie honey, honey from the Sejny county to several thousand beekeepers - producers of e.g. Podkarpacki honeydew honey applied to undergo certification and verification of compliance of their production process with specifications. Depending on the year, up to 37 of all the beekeepers certified until now could use the PDO or PGI logos. Producers of the Kurpiowski and Podkarpacki honeys showed the greatest interest in marking their honeys with the EU certification logo in contrast to the beekeepers from the Sejny, Dolny Śląsk and Pomorze Zachodnie regions whose interest in the certification can be considered insignificant. The research covering the 2010-2016 period indicates that the certification challenge was taken by the beekeeper leaders, most interested and involved in the protection and registration of honey [Borowska 2010a]. It would seem that their attitude to pave the way in the administrative procedures of certification would inspire and encourage other beekeepers to certify their honeys, but such hopes proved to be futile. The reasons for that, both objective and subjective, were many. The first ones included the excessive formal documentation, time-consuming information recording requirements of the multilevel production control procedure, the requirement to submit several free samples for laboratory 
examination, the meticulous identification of production volume and registration of customers, the relatively long waiting time for the reimbursement of costs of participation in the food quality systems under RDP 2007-2013 and, as emphasized by almost all beekeepers (92\%) except for the Drahim honey producers, lack of pricing bonuses in the case of premium quality honeys (with PDO or PGI logo) if compared with the uncertified varietal honeys offered on the local markets etc. As regards the subjective reasons, they include additional obligations arising from the declaration of certification, observant attitude of producers towards the certification and control system, inclination to take decisions on the basis of experience gained by other beekeepers, lack of time, small scale of production etc.

\section{Volume and value of production of certified regional honeys}

For these several reasons in 2008-2015 the production of five certified regional honeys totalled only $322018 \mathrm{~kg}$ available for sales (except for the Podkarpacki honeydew honey in 2012 and 2014 and the heather honey from Bory Dolnoslaskie forests in 2015) (Table 2). In 2015 the total value of declared production of all 4 harvested honeys (except for the heather honey from Bory Dolnoslaskie forests) was estimated at about 906 thousand PLN (net price) compared with about 680 thousand PLN in 2014 (except for the honeydew honey that lacked honey flows that year) at production volume lower by $45.5 \%$. In the years $2011-2015$, the Drahim honey accounted for even $83.3 \%$ (i.e. $268331 \mathrm{~kg}$ ) of total production of all certified regional honeys, the Kurpie honey with $7.7 \%$ share and $24732 \mathrm{~kg}$ took the second position, further ranked the Podkarpacki honeydew honey $(4.8 \%)$ with $15386 \mathrm{~kg}$ production volume, the heather honey from the Bory Dolnośląskie forests $(2.2 \%)-7169 \mathrm{~kg}$, and the honey from Sejny county with production volume of $6400 \mathrm{~kg}(2 \%)$.

Table 2.

Production of certified regional honeys in the years 2011-2015 (in $\mathbf{~ k g ) ~}$

\begin{tabular}{|l|c|c|c|c|c|}
\hline \multicolumn{1}{|c|}{ Honey/years } & $\mathbf{2 0 1 1}$ & $\mathbf{2 0 1 2}$ & $\mathbf{2 0 1 3}$ & $\mathbf{2 0 1 4}$ & $\mathbf{2 0 1 5}$ \\
\hline $\begin{array}{l}\text { Honey from Lower Silesia } \\
\text { Forests }\end{array}$ & 955 & 2874 & 1170 & 40 & 0 \\
\hline Kurpie honey & 945 & 9722 & 8150 & 5169 & 80 \\
\hline $\begin{array}{l}\text { Sub-Carpathian honeydew } \\
\text { honey }\end{array}$ & 4350 & 0 & 9786 & 0 & 1250 \\
\hline Drahim honey & 38391 & 37800 & 62240 & 51400 & 78500 \\
\hline The honey from Sejny & & 1500 & 1100 & 500 & 3300 \\
\hline TOTAL & $\mathbf{4 4 6 4 1}$ & $\mathbf{5 1 ~ 8 9 6}$ & $\mathbf{8 2 ~ 4 4 6}$ & $\mathbf{5 7} \mathbf{1 0 9}$ & $\mathbf{8 3} \mathbf{1 3 0}$ \\
\hline
\end{tabular}

Despite the fact that in 2015 honey production in Poland exceeded $22058 \mathrm{t}$, compared to $12836 \mathrm{t}$ in 2014, this cannot, unfortunately be said as regards the PGI heather honey of Lower Silesia Forests, which was absent on the Polish market in 2015, and in 2014 only $40 \mathrm{~kg}$ was sold, or about a PDO certified Sub-Carpathian honeydew honey. In both cases, the weather was to blame, i.e. late, short and unproductive heather blooming time, and drought which resulted in honeydew deficit. Those bee-keepers (including those certified) who decided to transport their hives to heather lands for a few days incurred losses, not only due to expensive transport (the heather lands are located approx. $200 \mathrm{~km}$ away from apiaries), but first of all due to weakening of bee colonies and the need to feed them in winter. Due to the 2014 drought in the Sub-Carpathian region, which resulted in a production volume of merely $862 \mathrm{t}$ (which accounted for $6.7 \%$ of the 
domestic production as compared to the $2651 \mathrm{t}$ in 2015 - a volume increase by $206 \%) 13$ hitherto certified producers of the Sub-Carpathian PDO certified honeydew honey did not collect any honey at all. Only one bee-keeper declared that his production would by 16.11 .2016 amount to $1250 \mathrm{~kg}$, but it remains a mystery until the end of the season whether this declaration will be fulfilled. It is worth to remember what happened in 2015 as regards the PGI certified kurpiowski polyfloral honey. According to GIJHARS database, 11 bee-keepers declared that in 2015 they collected only $80 \mathrm{~kg}$ of the PGI certified honey. However, such a low scale of production did not result from polyfloral honey deficit on the traditional area of its origin, i.e Kurpie region. The Kurpiowski honey may be marketed only as a polyfloral nectar honey with a possible addition of honeydew. It turned out that in 2015 the bee-keepers obtained record quantities of honey in Kurpie region, as it was the case in any other Polish region in 2015. However, due to a very high demand for honey from that region, the majority of the Kurpie bee-keepers sold their honey under a general brand instead of branding it as PGI.

\section{Price of regional honey}

The variety of honey as well as distance of apiaries from honey flows (migratory hives - high costs of transport) and points of sale (metropolitan areas, markets in cities, places frequently visited by tourists, etc.) have significant impact on the price of honey. For years the multifloral and rape honeys as well as the regional honeys analysed here have been cheaper than the most expensive heather and coniferous honeydew honeys, and the honeys sold in cities (including the city marketplaces) or places frequented by tourists have been a few dozen percent more expensive than honeys sold in other places or the apiaries. Depending on the year, the prices of multifloral and rape honeys were the lowest. The comparison of prices of the Drahim honey varieties in the years 2013-2016 shows that $1 \mathrm{~kg}$ of the lime honey was by about $20-25 \%$ and the heather by over $100 \%-112 \%$ more expensive than the multifloral honey or canola honey (Table 3 ).

In contrast, the gross price difference between the buckwheat honey and heather honey fell within the range of $70 \%-75 \%$. In addition to the dependencies mentioned, certain regularity can be observed, namely that smallest unit packing, the higher price per $1 \mathrm{~kg}$. The beekeepers seek solutions that would eliminate profit margins, especially charged by the intermediaries in business (e.g. the retailers), usually by using the direct sales system such as "face to face" or roadside sales, or try to minimize profit margins scale by cooperation with distributors who are reliable trading partners (i.e. those who pay liabilities in due time, effect payments, systematically order successive batches etc.). For example, 10 years ago the price of heather honey sourced from Lower Silesia Forests, due to its characteristic composition, was by PLN 3-8 (EUR 1-2) per $1 \mathrm{~kg}$ higher than the price of other heather honeys ${ }^{1}$. In the years of favourable weather (especially in 2012-2013), the price ranged from PLN 12 to even PLN 30 per kilo (i.e. EUR $2.8-7.2 / \mathrm{kg}$ ), especially if the product was marketed at international fair or in Warsaw. Honey producers from Sejny region did not experience such a big price range in terms of direct sales in the area of the honey production, i.e. Sejny and Suwałki poviat, although they admit that the price of a PDO labelled honey in a capital of a province would be approx. 20-25\% higher than in the production area, and in case of a big city (such as Warsaw) the price may be even 90-100\% higher than in the apiary. The price of the PGI Kurpiowski honey obtained in direct sales by producers in the local

${ }^{1}$ List of Traditional Products OJ C 179/15, 1.8.2007, Council Regulation No. 510/2006 (EC) „Miód wrzosowy z Borów Dolnośląskich" No WE: PL/PGI/005/ 0449/18.02.2005 [Heather Honey from Lower Silesia Forest] 
market between 2011 - 2015, increased on average by approx. 50 \%, while the price range reached +/- $10 \%$. However, the producers' long-term price strategy assumes that the direct sales price be maintained at the level of PLN 25-30/kg, which guarantees a favourable price in relation to the high product quality.

Table 3.

Average price of PDO and PGI certified honey in direct sales and purchasing power of an average monthly salary in Poland in relation to a price of certified honey in direct sales in 2011 and in 2015

\begin{tabular}{|l|c|c|c|c|}
\hline \multirow{2}{*}{ Honey } & \multicolumn{2}{|c|}{$\begin{array}{c}\text { Average price of PDO } \\
\text { and PGI certified } \\
\text { honey in direct sales } \\
\text { (PLN/ kg) }\end{array}$} & $\begin{array}{c}\text { Purchasing power of an average } \\
\text { monthly salary in Poland in } \\
\text { relation to a price of certified } \\
\text { honey in direct sales (kg) }\end{array}$ \\
\cline { 2 - 5 } & $\mathbf{2 0 1 1}$ & $\mathbf{2 0 1 5}$ & $\mathbf{2 0 1 1}$ & $\mathbf{2 0 1 5}$ \\
\hline $\begin{array}{l}\text { Honey from Lower Silesia Forests } \\
\text { (PGI) }\end{array}$ & 40 & bd & 85 & bd \\
\hline Kurpie honey (PGI) & 20 & 40 & 170 & 97 \\
\hline $\begin{array}{l}\text { Sub-Carpathian honeydew honey } \\
\text { (PDO) }\end{array}$ & 38 & 47,50 & 89 & 82 \\
\hline The honey from Sejny (PDO) & bp & 33,5 & bp & 116 \\
\hline Drahim honey (PGI) - rape & 30 & 35,4 & - & - \\
\hline - multiflower & 30 & 35,4 & 113 & 110 \\
\hline - lime & - & 47,6 & 113 & 82 \\
\hline - buckwheat & 31 & 35,8 & - & 109 \\
\hline - heather honey & 50 & 61,5 & 110 & \\
\hline
\end{tabular}

bp-certified honey not produced bd - no honey available, no data available

Source: Own calculations based on GUS "Przeciętne miesięczne wynagrodzenie w gospodarce narodowej" http://stat.gov.pl/obszary-tematyczne/rynek-pracy/pracujacy-zatrudnieni-wynagrodzenia-kosztypracy/przecietne-miesieczne-wynagrodzenie-w-gospodarce-narodowej-w-latach-1950-2015,2,1.htm (06.06.2016)

The Sub-Carpathian PDO honeydew honey, as other honeydew honeys, is relatively expensive due to its scarce production and big seasonal volatility. While selling the product directly with a PDO label in 2015, its producer cashed approx. PLN 45-47/ kg (EUR 11.3/kg). The honey could be bought for a similar retail price at a shop run by Provincial Association of Bee-Keepers. Honeydew honey without PDO label was approx. 25 \% cheaper, i.e. its price was PLN 9-10/kg (EUR 2-2.5/kg). In addition, considering that honeydew honey supply was bigger in 2015 in comparison to previous years, which made its retail prices drop to the average of PLN 32.6/kg, the PDO certified honey was a less attractive product in terms of price for those purchasers who did not pay attention to a quality certificate or were not aware of what the certificate meant. Moreover, its retail price in 2015 grew by $11 \%$ in comparison to 2013. Drahimski honey (PGI) brand is reserved for five different honeys, including: buckwheat, rapeseed, heather, lime and polyfloral honey. In 2015, they could be bought directly from an apiary or ordered through Internet, in which case the price was increased by the cost of delivery. The most expensive was the heather honey (PLN 61.5/kg - EUR $14.75 / \mathrm{kg}$ ). Rapeseed, buckwheat and polyfloral honeys cost PLN 35.5/kg (EUR 8.5), and lime honey cost $34 \%$ more. During the 5 years under consideration, the prices of honeys increased by $15.5 \%$ in case of buckwheat honey, $18 \%$ in case of polyfloral and rapeseed and by $23 \%$ in case of heather honey.

\section{Distribution of regional honeys}

According to the data from bee-keepers' organizations, direct sale is the basic sales channel for honey in Poland. $79 \%$ of the whole production is sold directly. Bee-keepers supply approx. $12 \%$ 
of their honey for industrial buying-in, and nearly $8.9 \%$ goes to retail. In 2015 , only $0.1 \%$ of all the honey production in Poland was intended for industry [Semkiw 2015, Borowska 2011]. The sales structure of Polish PDO and PGI certified regional honeys in the period 2011-2015 points to a domination of direct distribution channels, with avoidance of wholesale buying-in and marginalization of agents who sell honey to final consumer. The most popular type of honey marketing is to do it directly from the apiary by the bee-keeper himself or his family members. Assuming direct sales as $100 \%$, as much as $70 \%$ of Kurpiowski honey production, and $63 \%$ of Drahimski honey production is purchased by consumers who visit apiaries. In case of SubCarpathian honeydew honey, it is approx. $55 \%$, and for honeys from Lower Silesia Forest and from Sejny it is $38 \%$ and $34 \%$, respectively. In case of the latter, further $33 \%$ is sold at local open-air markets and during public events (fairs, etc.). Also heather honey and honeydew honey find their purchasers in this way (31\% and $27 \%$, respectively). Another convenient option of direct contact with client is when bee-keepers participate in industrial fairs throughout Poland, which accounts for 4-6 \% of the direct sales structure of 3 honeys (Drahimski, heather, Kurpiowski) and $18 \%$ in case of honeydew honey, apart from the honey from the Sejny region.

\section{Discussion and comments}

Taking into account the strengths and weaknesses of the current availability of the regional honeys with PDO and PGI certification on the Polish market, mainly the local markets, the low interest of the beekeepers in the certification takes the first place (Table 4). In the case of beekeepers running small apiaries, the costs of participation in the system and time-consuming procedure discourage them from taking the trouble of distinguishing their products on the market with a logotype. In their opinion, their honey, whether distinguished with PDO or PGI logo or not, will still be sold due its values and quality, especially to the long-term loyal customers, though not under a registered name. The persistent question about the future of certified honeys should, however, be considered. Should it be expected that as long as the marked products are not considered by consumers as distinctive compared with other conventional products of the same category (or other not quality certified honeys), and as long as the producers do not earn sufficient profit from their competitive advantage (whether stimulated or not by promotional and information campaigns), they will disappear from the market in a natural way? Given the growing beekeepers' awareness of identifiability and recognition through product, in contrast to their current anonymity on the market, such a pessimistic scenario probably should not be considered. Integrated activities taken by groups, especially of educational and marketing nature, are a chance for them. Although supporting the marketing with professional advice is worth considering, not everyone can afford it, the economic factor (stimulus), including the price achieved from the sale of honey, still constitutes the basis for making the production decisions. The current support offered under RDP 2007-2013 program to the producers of regional honeys who participate in the food quality systems included 16 beekeepers only. Within the 27 decisions on granting aid, the amounts from PLN 429 to PLN 3200 were paid, which is the maximum that a beneficiary could obtain annually in five successive years. In the opinion of the author, the amounts of aid are not sufficient to stimulate interest in such instrument of support or enhance interest in the certification of regional honeys produced in the regions anyway. Moreover, except for the Drahim honey, the additional costs and time of preparation and implementation of the product quality compliance procedure - i.e. the certification, do not translate as assumed into the higher price of honeys with PDO or PGI logos. 
Selected strengths and weaknesses of certified regional honeys in Poland

\begin{tabular}{|c|l|l|}
\hline Honey & \multicolumn{1}{|c|}{ Strengths } & \multicolumn{1}{|c|}{ Weaknesses } \\
\hline $\mathbf{1}$ & $\begin{array}{l}\text { Professional apiaries and commercial production; } \\
\text { Development of product brand; Identifiability of product on } \\
\text { the market; Availability through modern distribution } \\
\text { channels (e-commerce) }\end{array}$ & $\begin{array}{l}\text { Joint action through integration of ties } \\
\text { of association members }\end{array}$ \\
\hline $\mathbf{2}$ & $\begin{array}{l}\text { Honey harvest and local beekeeping events; Consumers' } \\
\text { interest in product, especially local consumers; Consumer } \\
\text { education through direct contact with a beekeeper (direct } \\
\text { sales ), Production potential }\end{array}$ & $\begin{array}{l}\text { Supply lower than demand; Decreasing } \\
\text { interest in product certification }\end{array}$ \\
$\mathbf{3}$ & $\begin{array}{l}\text { Cooperation and exchange of experience among certified } \\
\text { beekeepers; Recognition of product name }\end{array}$ & $\begin{array}{l}\text { Certification of production by only a few } \\
\text { leaders of the Dolnoślaskie Association } \\
\text { of Beekeepers; Continuity of annual } \\
\text { production (lacking honey flow) }\end{array}$ \\
\hline $\mathbf{4}$ & $\begin{array}{l}\text { Sales of honey in an apiary; The first regionally bilateral } \\
\text { product (Poland and Lithuania) }\end{array}$ & $\begin{array}{l}\text { Too few certified producers (1); } \\
\text { Marginal production volume; Low } \\
\text { availability for consumers on the } \\
\text { market; Promotion and marketing }\end{array}$ \\
\hline $\mathbf{5}$ & $\begin{array}{l}\text { Sales of product supported by the flagship store of the } \\
\text { Provincial Association of Beekeepers in Rzeszów; } \\
\text { Production potential }\end{array}$ & $\begin{array}{l}\text { Honey harvested not every year; } \\
\text { Promotion and marketing }\end{array}$ \\
\hline
\end{tabular}

1-Drahim honey, 2- Kurpie honey, 3- Honey from Lower Silesia Forests, 4- The honey from Sejny, 5- Sub-Carpathian honeydew honey

Source: own calculations

\section{Conclusions}

On the basis of author's own research and the analysis of data provided by GIJHARS, Agency for Restructuring and Modernization of Agricutlure (ARiMA), the Institute of Pomology and Floriculture, Apiculture Division in Pulawy relating to five certified honeys with PDO, PGI European Union certification in Poland in the years 2008-2015 the following conclusions can be drawn

1) Direct distribution channels dominate in sales of all regional honeys.

2) All certified producers of regional honeys sell their products mainly in the apiaries.

3) Approximately $86.5 \%$ of the beekeepers declare participation in local events (such as the beekeeper days, fairs, bazaars etc.) as well as sales at neighbouring markets. However, considering the developing character of the Drahim honeys business their producers do not exclude, and rather would welcome, an increasing role of indirect channels of sale, and especially elimination of other ways of sale, and would like to focus on the specialty health food stores, ecological herbal stores, and small local retail stores with development of the e-commerce activity.

4) The studies carried out among the associations of producers of the certified regional honeys in 2016 confirmed their continuing interest in participation in various local and regional cultural events (trade fairs, beekeepers' days, festivals etc.) which give them the opportunity to promote and sell their products as well as educate the consumers.

5) The niche character and small production volumes at present, especially of the three reional honeys (including the honey from Sejny county, the heather honey from Bory Dolnoslaskie forests and the Podkarpacki honeydew honey) make such honeys unavailable to a wider range of consumers. Moreover, in consequence of little interest on the part of the large group of the beekeepers in the certification of compliance of their production process with specifications their products cannot be upgraded against honeys of the same category or marked with PDO or PGI logo as products of repeatable high quality. Therefore, at this stage of building the regional and traditional food market in Poland, it is hard to call the certification a pro-development activity, with 
a few exceptions namely the professional and non-amateur beekeepers focused at keeping commercial apiaries (the Drahim honey).

\section{Bibliography}

1. Borowska A. 2009. Distribution of traditional and regional food products in the European Union experiences and an example for Poland. [in:] Żywność regionalna i tradycyjna - aspekty surowcowe, technologiczne i ekonomiczne: materiały na międzynarodową konferencję naukowo-promocyjną. Uniwersytet Warmińsko-Mazurski, Olsztyn 25-26. 11. 2009, Olsztyn, pp. 27-29

2. Borowska A. 2010b. The role of traditional and regional food products in rural development in Poland. Socialiniai Tyrimai / Social Research 2010, nr 1 (18), pp. 40-52

3. Borowska A. 2011. Condition and perspectives of development of the beekeeping in Poland with particular consideration of regional honeys. Scientific Papers of SGGW in Warsaw. Problems of Agriculture of the World 2011, Volume 11 (26), book 4, pp. 37-47

4. European Commission, Agriculture and Rural Development http://ec.europa.eu/agriculture/quality/door/list.html (06.06.2016)

5. Fragata A., Tiberio M. L., Teixeira M. S. 2007. Traditional products with protected designation of origin: policy and market situation in Portugal. New Medit No. 2, pp. 4 - 12

6. Kühne B., Vanhonacker F., Gellynck X., Verbeke W. 2010. Innovation in traditional food products in Europe: Do sector innovation activities match consumers' acceptance? Food Quality and Preference 21/2010, p. 629 $-638$

7. List of Traditional Products OJ C 179/15, 1.8.2007, Council Regulation No. 510/2006 (EC) "Miód Wrzosowy z Borów Dolnośląskich" Nr WE: PL/PGI/005/ [Heather Honey from Lower Silesia Forest]

8. Pieniak, Z., Verbeke, W., Scholderer, J., Brunso, K., Olsen, S. O. 2008. Impact of consumers' health beliefs, health involvement and risk perception on fish consumption: A study in five European countries. British Food Journal, 110(8-9), pp. 898-915,

9. Popovics A. 2006. A review of traditional Hungarian products' reputation with a special focus on consumer behaviour. Studies in Agricultural Economics No. 105, pp. 71 - 86,

10. Semkiw P. 2015. The beekeeping sector in Poland in 2015. Research Institute of Pomology and Floriculture, Division of Apiculture in Puławy pp. 5-15.

11. Vecchio R., Annunziata A. 2011. The role of PDO/PGI labelling in Italian consumers' food choices. Agricultural Economics Review, vol. 12, no. 2, pp. 80 - 98,

12. Verbeke W., Roosen J. 2009. Market differentation potential of country-of-origin, quality and traceability labelling. The Estey Centre Journal of International Law and Trade Policy vol. 10 No. 1, pp. $20-35$

13. Żakowska-Biemans S. Bezpieczeństwo żywności jako czynnik determinujący zachowania konsumentów na rynku żywności Probl. Hig. Epidem.2011, 92(3), pp. 621-624,

14. Borowska A. 2010a. Economic and non-economic conditions for traditional food production in Poland (Uwarunkowania ekonomiczne i pozaekonomiczne produkcji żywności wysokiej jakości w Polsce).

Wydawnictwo SGGW, p. 48-54 